\title{
Gender-Based Violence in Mali: A Hidden Disaster in Schools
}

\author{
F. Dembélé $1^{*}$, Z. Keita ${ }^{2 *}$, S. Goita ${ }^{3}$, O. Sylla ${ }^{4}$ \\ ${ }^{1}$ Centre National d'Appui à la lutte contre la Maladie, Bamako, Mali \\ ${ }^{2}$ Independent Health Consultant, Rabies Association in West Africa (RIWA-Mali), Bamako, Mali \\ ${ }^{3}$ Social Science Consultant, Policy Analyst and Population and Health Programs, Bamako, Mali \\ ${ }^{4}$ Reference Health Center of Youwarou, Regional Directorate of Health of Mopti, Bamako, Mali \\ Email: *kitafilani@gmail.com, ${ }^{\star}$ zakariakeita10@gmail.com
}

How to cite this paper: Dembélé, F., Keita, Z., Goita, S., \& Sylla, O. (2020). Gender-Based Violence in Mali: A Hidden Disaster in Schools. Open Journal of Social Sciences, 8, 242-251.

https://doi.org/10.4236/jss.2020.82019

Received: September 30, 2019

Accepted: February 25, 2020

Published: February 28, 2020

Copyright (c) 2020 by author(s) and Scientific Research Publishing Inc. This work is licensed under the Creative Commons Attribution International License (CC BY 4.0).

http://creativecommons.org/licenses/by/4.0/

(c) (i) Open Access

\begin{abstract}
Introduction: Violence against girls has always been considered as a factor of deschooling in French-speaking Sub-Saharan Africa. It is often inadequately reflected in Education for all policies and programs. The objective is to study the frequency and characteristics of gender-based violence at the tertiary vocational training institute (IFP-TER) in Kayes/Mali. Methodology: The survey was conducted for four months (September 1 to December 30, 2012). A descriptive cross-sectional study was conducted in the establishment of IFP-TER Kayes. The study population consists of all the girls in the school. Extensive sampling was done. Individual interviews were conducted and data entered on the Epidata 3.1 software and analyzed on SPSS version 16.0. Results: 357 girls were surveyed, of whom 336 experienced at least one form of violence. Of the girls who were abused, $52.4 \%$ experienced sexual violence, $77 \%$ experienced physical violence, and $47.4 \%$ experienced emotional abuse. The vast majority of assaults took place at school (50.9\%) and $40 \%$ in host families of students. Of the girls surveyed, $77 \%$ said they were victims of physical violence, jostling; punches and slaps were frequently cited as types of violence with $69.1 \% ; 40.7 \%$ and $36.4 \%$. Girls were victims of sexual violence $52.4 \%$ of cases, threats and harassment were the most cited with respectively $75.1 \%$ and $74.8 \%$; rape was cited in $41.9 \%$ of cases. Blackmail predominated among victims of psychological violence (81.5\%). Conclusion: The proportion of girls who are abused (94.3\%) raises the issue of gender-based violence at the level of IFP-TER. Faced with this situation; it seems advisable to lead an effective fight with the involvement of the various actors in the Kayes region.
\end{abstract}

\section{Keywords}

Violence, Youth, Sex, School Environment, Mali 


\section{Introduction}

The United Nations defines violence against women as "all acts of violence directed against the female sex, and causing or likely to cause physical, sexual or psychological harm or suffering, including the threat of such acts, arbitrary deprivation of liberty, whether in public life or in private life" (Etude approfondie de toutes les formes de violence à Pégard des femmes, 2006). This definition obscures gender violence in schools, which is a major public health problem. According to UN estimates, $35 \%$ of women in the world have experienced physical and/or sexual violence (not counting sexual harassment) at some points in their lives. This percentage rises to $70 \%$ in some national studies (ONU Femmes, s. d.).

While educational institutions are recognized as places of learning, development and empowerment, schools are too often places of discrimination and violence, especially towards girls. In 2004, UNICEF's report on the state of the world's children indicated that "sexual, physical and psychological violence perpetrated by teachers against girls is common". Two years later, in 2006 the UN Secretary-General's report on violence against children also reported numerous school-related violence, such as corporal punishment, harassment, ill-treatment and abuse sexual violence (Devers et al., 2012). Field surveys carried out in schools in sub-Saharan Africa indicate that gender-based violence is widespread and daily, affecting girls in the first place. The specificity of sexual violence in schools is that it is recognized as one of the causes of girls' school dropout.

In Mali, $83.3 \%$ of adults and $82.5 \%$ of children cited corporal punishment as one of the main forms of physical violence in school. In addition to this form of violence, school could also be the place of gender-based violence. Sexual harassment of a teacher on a student is by far the most cited type of sexual violence (71.1\%). Emotional abuse has adverse effects on the child's personal and emotional development, with self-esteem (29.7\%) and depression (47.5\%) among respondents (Antonowicz, 2010).

The negative consequences on the school performance of the victims of these abuses are multiple, the pupils lose interest for their studies, have difficulties to concentrate, abstain from participating in class, develop tendencies depressive and sometimes suicidal. The objective is to study the frequency and characteristics of gender-based violence at the "Institut de Formation Professionnelle Tertiaire (IFP-TER)” of Kayes in Mali.

\section{Methodology}

A descriptive cross-sectional study was conducted for four months (1 September to 30 December 2012) in the IFP-TER of Kayes.

The study population consists of all the girls in the school. Were included all IFP-TER girls who accepted the survey conditions, who attended at the "Institut de Formation Professionnelle Tertiaire (IFP-TER)” of Kayes from 2011 to 2012 school year. The IFP-TER of Kayes is an establishment located in the center of 
the city of Kayes receiving students as well as professionals coming from all horizons. The objective of the institute is to provide vocational training which is a learning process that enables an individual to acquire the skills (skills and competences) necessary for the practice of a professional activity. It is in principle related to the world of work.

For the realization of the study we used a pre-coded and pre-test questionnaire inspired by the one used in the research action on gender equity conducted in 2008 by Ahlem Belhadj and Feika Bagbag to the delegation of the national office of the family and the population (ONFP) of Douar Hicher (Belhadj \& Bagdad, 2008). This questionnaire has been adapted to the issue of violence and dropout of girls from IFP-TER Kayes. The data collected by the questionnaire related to the socio-demographic characteristics of girls and abusers, violence experienced by girls. The information was collected on forms with questions that participants should answer during an individual interview. These data were entered on the software Epi data 3.1 and analyzed on SPSS version 16.0.

\section{Ethical considerations}

We have obtained the authorization by sending a correspondence to the school management for the conduct of the survey with a copy of the questionnaire. Participation in the survey was voluntary; the girls verbally gave consent to participation. The information from the interview with the participants was confidential, anonymity was guaranteed no volunteer was identifiable from these questionnaires.

\section{Results}

Three hundred and fifty-seven (357) girls were interviewed for this study, 336 (94\%) of whom were abused.

\section{Sociodemographic characteristics of female students}

The average age of the victims was 18.9 years with extremes of 15 and 23 years. Half (50.4\%) of our study population was from the city of Kayes. They attended classes 1, 2, 3 and 4 respectively in $19.9 \%, 28.3 \%, 23 \%$ and $28.8 \%$.

Singles were the majority in the study population with $69.5 \%$ followed by married women (16.5\%). In our study population, $60.2 \%$ had a close relative as guardian and $35.9 \%$ as a distant parent. The majority of female students (53.5\%) shared their room with other family members (Table 1 ).

\section{Sociodemographic characteristics of abusers}

The average age of sex offenders was 31.8 years with extremes of 19 and 68 years. Primary, secondary and higher levels were respectively 15\%, 45\% and $26.8 \%$. Among the abusers were smokers (15.3\%) and drug addicts (2.9\%). The boyfriends were designated as aggressors in $32.6 \%$ of cases, and teachers in $31.3 \%$ of cases and close relatives in $18.2 \%$ of cases (Table 2 ).

The assailants of physical abuse were at primary, secondary and higher levels in $14.5 \%, 40 \%$ and $29 \%$, respectively. Abusers taught victims (32\%) (Table 3 ). The assailants of physical abuse were at primary, secondary and higher levels in 
$16.7 \%, 41.9 \%$ and $27.8 \%$ respectively. The perpetrators taught the victims (31.5\%) (Table 4).

\section{Characteristics of violence}

The majority of girls were victims of some types of violence $(94.3 \%)$. From the girls who were abused, $52.4 \%$ have had sexual violence, $77 \%$ physical violence,

Table 1. Sociodemographic characteristics of female students.

\begin{tabular}{|c|c|c|c|}
\hline Caracteristics & Modalities & Number & $\%$ \\
\hline \multirow[t]{2}{*}{ Origin } & Kayes & 180 & 50.4 \\
\hline & Hors Kayes & 177 & 49.6 \\
\hline \multirow[t]{4}{*}{ Classes } & 1 & 71 & 19.9 \\
\hline & 2 & 101 & 28.3 \\
\hline & 3 & 82 & 23.0 \\
\hline & 4 & 103 & 28.8 \\
\hline \multirow[t]{5}{*}{ Marital status } & Single & 248 & 69.5 \\
\hline & Fiancee & 41 & 11.5 \\
\hline & Married & 59 & 16.5 \\
\hline & Concubinage & 1 & 0.3 \\
\hline & Divorcee & 8 & 2.2 \\
\hline \multirow[t]{3}{*}{ Place of dormitory } & Alone in the room & 147 & 41.2 \\
\hline & Living room & 19 & 5.3 \\
\hline & With others & 191 & 53.5 \\
\hline \multirow[t]{4}{*}{ Tutor of the students } & Close relatives & 215 & 60.2 \\
\hline & Distant relatives & 128 & 35.9 \\
\hline & Friend & 12 & 3.4 \\
\hline & Alone & 2 & 0.5 \\
\hline
\end{tabular}

Table 2. Sociodemographic characteristics of the abuser of sexual violence.

\begin{tabular}{cccc}
\hline Caracteristics & Modalities & Number & $\%$ \\
\hline $\begin{array}{c}\text { Level of education of the } \\
\text { abuser }\end{array}$ & Primary & 47 & 15 \\
& Secondary & 141 & 45 \\
& University & 84 & 26.8 \\
& Alphabetized/Koranic School & 32 & 10.2 \\
Relationship between the & No & 9 & 2.9 \\
victim and the aggressor & Parent/Tutor & 57 & 18.2 \\
& Teacher & 98 & 31.3 \\
& Co-landlord & 35 & 11.2 \\
& Boyfriend & 102 & 32.6 \\
& No relation & 21 & 6.7 \\
\hline
\end{tabular}


Table 3. Sociodemographic characteristics of the abusers of physical violence.

\begin{tabular}{cccc}
\hline Caracteristics & Modalities & Number & $\%$ \\
\hline $\begin{array}{c}\text { Level of education of the } \\
\text { abuser }\end{array}$ & Primary & 40 & 14.5 \\
& Secondary & 110 & 40 \\
& University & 80 & 29.1 \\
& Alphabetized/Koranic School & 34 & 12.4 \\
Relationship between the & No & 11 & 4 \\
victim and the aggressor & Parent/Tutor & 48 & 17.5 \\
& Teacher & 88 & 32 \\
& Co-landlord & 22 & 8 \\
& Boyfriend & 107 & 38.9 \\
\hline
\end{tabular}

Table 4. Sociodemographic characteristics of abusers of psychological violence.

\begin{tabular}{cccc}
\hline Caracteristics & Modalities & Number & $\%$ \\
\hline $\begin{array}{c}\text { Level of education of the } \\
\text { abuser }\end{array}$ & Primary & 45 & 16.7 \\
& Secondary & 113 & 41.9 \\
& University & 75 & 27.8 \\
& Alphabetized/Koranic School & 28 & 10.4 \\
\multirow{2}{*}{$\begin{array}{c}\text { Relationship between the } \\
\text { victim and the aggressor }\end{array}$} & No & 9 & 3.3 \\
& Parent/Tutor & 25 & 9.3 \\
& Teacher & 85 & 31.5 \\
& Co-landlord & 24 & 8.9 \\
& Boyfriend & 70 & 25.9 \\
\hline
\end{tabular}

and $47.4 \%$ emotional abuse. The vast majority of aggressions took place at school (50.9\%) and $40 \%$ in host families of students. Of the girls surveyed, $77 \%$ said they were victims of physical violence, jostling; punches and slaps as types of violence with $69.1 \% ; 40.7 \%$ and $36.4 \%$. Girls were victims of sexual violence $52.4 \%$ of cases, threats and harassment were the most cited with respectively $75.1 \%$ and $74.8 \%$; rape was cited in $41.9 \%$ of cases. The blackmail predominated among victims of psychological violence (81.5\%) (Table 5).

\section{Discussion}

Almost all girls in school have experienced some types of gender-based violence. This study has highlighted the extent of gender-based violence occurring in all areas of life: the family, school and the street.

The limit of this study is that it does not allow to extrapolating the results at the national level since there was not a sampling on the whole territory, which is 
Table 5. Characteristics of the violence.

\begin{tabular}{|c|c|c|c|}
\hline Caracteristics & Modalities & Number & $\%$ \\
\hline \multirow[t]{2}{*}{ Violence } & Yes & 315 & 94.3 \\
\hline & No & 19 & 5.7 \\
\hline \multirow[t]{3}{*}{ Types of violence } & Sexual & 165 & 52.4 \\
\hline & Physical & 243 & 77 \\
\hline & Psychological & 149 & 47.4 \\
\hline \multirow[t]{3}{*}{ Places of aggression } & School & 160 & 50.9 \\
\hline & Family & 126 & 40 \\
\hline & Street & 29 & 9.1 \\
\hline \multirow[t]{4}{*}{ Types of sexual violence } & Sexual harassmen & 234 & 74.8 \\
\hline & Rape & 131 & 41.9 \\
\hline & Sexual intercourse deemed humiliating & 20 & 6.4 \\
\hline & Threat of the aggressor & 235 & 75.1 \\
\hline \multirow[t]{6}{*}{ Types of physical violence } & Knocking with the fist/object & 112 & 40.7 \\
\hline & Slap/throw an object & 100 & 36.4 \\
\hline & Throttle/burn & 56 & 20.4 \\
\hline & Push/shake & 190 & 69.1 \\
\hline & Threaten with a knife & 42 & 15.3 \\
\hline & Kick/beat, drag & 95 & 34.5 \\
\hline \multirow{4}{*}{$\begin{array}{c}\text { Types of psychological } \\
\text { violence }\end{array}$} & Refuse to speak & 190 & 70.4 \\
\hline & Insulting/guilty & 156 & 57.8 \\
\hline & Humiliation/ frustration & 110 & 40.7 \\
\hline & Blackmail & 220 & 81.5 \\
\hline
\end{tabular}

immense with a multicultural population.

The average age of the victims was 18.9 years higher in the study conducted in Ivory Coast where the average was 16 years (N'GUESSAN et al., 2004). The study conducted in Tambacounda, Senegal found $26.5 \pm$ (10.08) years as the average age of the abused (Leye et al., 2017). During the pubertal period in the girl, her body is in full change becoming the object of attraction for young boys and adults. In addition, in the African context, during this period of life, children usually go shopping instead of parents and, in a solitary situation, the opportunity is given to the abuser to commit sexual violence (Buambo-Bamanga et al., 2005). As in our series, most authors (N'GUESSAN et al., 2004; Traore et al., 2010) reported high rates of teenage sexual assault. This could be explained by their high vulnerability marked by the advanced age of the aggressors compared to the victims. Indeed, the average age of sexual abusers was 31.8 years. This fact is almost similar to that observed in Tambacounda, Senegal, which is $32.5 \pm$ (13.8) years old (Leye et al., 2017). In addition to the age difference, there is 
another factor of vulnerability, such as internally displaced students from the north of the country.

According to our study, 313/357 (87.7\%) cases of sexual violence were recorded, of which 270/357 (75.6\%) girls experienced all three types of violence. In Senegal $9.6 \%$ of high school and college students say they have been "bothered by sex stories" and among this population $62 \%$ are girls (Coulibaly, 2013). In the cross-country analysis of the baseline study in Ghana, Kenya, and Mozambique, a sexual abuse rate of $29.8 \%$ was found in Kenya, $29.3 \%$ in Mozambique, and $22.6 \%$ in Ghana (Unicef, 2012). A study conducted by MBassa Menick in Cameroon in 2001 in urban areas gave 16\% of girls mention cases of sexual abuse. Moreover, studies reveal that the Burundian school community is the victim of gender stereotypes and sexual violence with its corollary of pregnancies (2356 cases in primary and 2351 cases in high school in 2014), early and unwanted marriages (Nsengiyumva, 2018). In one of the states of Southern India, a survey of school-aged girls also showed that they were exposed to harassment (Etude approfondie de toutes les formes de violence à 1 égard des femmes, 2006).

In the Transnational Analysis report of the baseline study in Ghana, Kenya, and Mozambique, a physical violence rate of $83.6 \%$ was found in Kenya, 59.7\% in Mozambique, and 78.2\% in Ghana (Unicef, 2012). In Ethiopia, 21\% of urban schoolchildren and $64 \%$ of rural schoolchildren reported ecchymosis and gibbous on their bodies because of parental punishment (Ketsela \& Kebede, 1997).

According to our study 270/357 (\%) girls were victims of psychological abuse. In the transnational analysis of the baseline study in Ghana, Kenya, and Mozambique it was found a rate of psychological violence of 34.2\% in Kenya, 31.5\% in Mozambique, and 62.6\% in Ghana (Unicef, 2012). The practice of threatening children to abandon or lock them out varied considerably from country to country. In the Philippines, for example, 48 percent of mothers reported threatening their children to abandon them for punishment. In Chile, only about $8 \%$ of mothers reported using blackmail (WHO \& UNAIDS, 2002); this type of violence was the most found in our study (81.5\%).

The place of sexual assault was 50.9\% for school and $40 \%$ for families in our study. Sexual pressure against girls is frequently exercised by adults outside schools, in 30\% of cases (Coulibaly, 2013). Young girls feel trapped because either they cannot find refuge at home or at school, which must be places of education and emancipation. A study conducted by MBassa Menick in Cameroon in 2001 in urban areas showed that $15 \%$ of cases reported abuse (touching and rape) occurred in the school setting (Menick, 2002). In an educational space in Ecuador, 22\% of adolescent girls reported having been sexually abused at school (Correia \& Bronkhorst, 2000). A study by Human Rights Watch on violence in eight schools in South Africa found that violence and sexual harassment against girls was endemic in many schools. Girls were raped in toilets, dormitories, and empty classrooms (Human Rights Watch (Organization) \& George, 2001).

In our study, sex aggressors were teachers (31.3\%). Similar in other studies, 
school is the most common place where many young women risk sexual coercion and harassment. Indeed, in Zimbabwe, a retrospective study of child sexual abuse cases reported over eight years (1990-1997) found high rates of sexual violence perpetrated by teachers in rural primary schools. Many of the victims were girls aged 11 to 13 , and penetrative sex was the most common type of sexual abuse (Nhundu \& Shumba, 2001).

In our study, rapes accounted for $41.9 \%$. At the global level, this fact is described in other studies where many women report that their first sexual experience was forced: $24 \%$ in rural Peru, $28 \%$ in Tanzania, $30 \%$ in rural Bangladesh and $40 \%$ in South Africa (Organisation mondiale de la santé, 2005). These sexual acts suffered as rapes denote the extreme severity of the violence making it more difficult to medical and psychosocial care of the victim. The rape could also have a consequence of unwanted pregnancy and sexual transmitted infections like HIV (Heise et al., 2002). Thus, during consultations, it is essential that the health care team keep from having any judgment or support that is too partisan and that can hinder the care of the victim. Violence against women is a phenomenon of sexist discrimination, incompatible with the principles of human rights (“Violence against women", 2020).

Therefore, the prevention of gender-based violence is essential at school. Education of youths, sensitization of victims to lodge a complaint, political engagement and justice could contribute to reduce gender-based violence. Crooks and al prevention of intimate partner violence among adolescents and young adults is a key strategy for reducing rates of gender-based violence (Crooks et al., 2019).

We must continuously think of developing new intervention in school and university using new technologies of information and communication.

\section{Conclusion}

In this study, the majority of girls experienced some form of violence (94.3\%), of which $77 \%$ had been physically abused, $52.4 \%$ had sexual violence and $47.4 \%$ had emotional abuse. These results demonstrate the problem of this scourge at the level of the Institut de Formation Professionnelle Tertiaire (IFP-TER) of Kayes especially since half of the violence had taken place in the school. This situation should encourage the education and health authorities to carry out awareness-raising activities among youths in order to reduce violence in schools. Therefore, it is crucial to develop and evaluate interventions of preventing gender-based violence in school.

\section{Acknowledgements}

We thank the young women of the IFM Kayes for their participation in the study and the direction for their authorization, which allowed the progress of the study.

\section{Conflicts of Interest}

The authors declare no conflicts of interest regarding the publication of this paper. 


\section{References}

(2020). Violence against Women. Wikipedia. https://en.wikipedia.org/w/index.php?title=Violence against women\&oldid $=93706375$ $\underline{9}$

Antonowicz, L. (2010). La violence faite aux enfants en milieu scolaire au Mali (p. 61). City: Education for Change Ltd.

Belhadj, A., \& Bagdad, F. (2008). Équité de genre et prévention de la violence à l'encontre des femmes. Recherche/action initiée par l'ONFP à Douar Hicher.

Buambo-Bamanga, S. F., Oyere-Moke, P., Gnekoumou, A. L., Nkihouabonga, G., \& Ekoundzola, J. R. (2005). Violences sexuelles à Brazzaville. Cahiers d'études et de recherches francophones/Santé, 15, 31-35.

http://www.jle.com/fr/revues/san/e-docs/violences sexuelles a brazzaville 265447/arti cle.phtml?tab=texte

Correia, M., \& van Bronkhorst, B. (2000). Ecuador Gender Review: Issues and Recommendations. Washington DC: World Bank.

Coulibaly, M. L. (2013). Les victimisations scolaires au Sénégal à l'épreuve de l'analyse de genre: De la construction socioculturelle et institutionnelle des violences sexuelles en Afrique subsaharienne. Recherches \& Éducations, 8, 65-80. http://journals.openedition.org/rechercheseducations/1564

Crooks, C. V., Jaffe, P., Dunlop, C., Kerry, A., \& Exner-Cortens, D. (2019). Preventing Gender-Based Violence among Adolescents and Young Adults: Lessons from 25 Years of Program Development and Evaluation. Violence against Women, 25, 29-55. https://doi.org/10.1177/1077801218815778

Devers, M., Henry, P. É., Hofmann, É., \& Benabdallah, H. (2012). Les violences de genre en milieu scolaire en Afrique subsaharienne francophone: Comprendre leurs impacts sur la scolarisation des filles pour mieux les combattre (p. 32). Ministère des affaires étrangères et européennes France.

Étude approfondie de toutes les formes de violence à l'égard des femmes (2006). Rapport du Secrétaire général A/61/122/Add.1 (p. 156). Nations Unies.

Heise, L., Ellsberg, M., \& Gottmoeller, M. (2002). A Global Overview of Gender-Based Violence. International Journal of Gynecology \& Obstetrics, 78, S5-S14.

https://doi.org/10.1016/S0020-7292(02)00038-3

Human Rights Watch (Organization), \& George, E. (2001). Scared at School: Sexual Violence against Girls in South African Schools. New York: Human Rights Watch.

Ketsela, T., \& Kebede, D. (1997). Physical Punishment of Elementary School Children in Urban and Rural Communities in Ethiopia. Ethiopian Medical Journal, 35, 23-33. https://europepmc.org/article/med/9293144

Leye, M. M. M., Ndiaye, P., Ndiaye, D., Seck, I., Faye, A., \& Tal Dia, A. (2017). Aspects épidémiologiques, cliniques et judiciaires des violences physiques faites aux femmes dans la région de Tambacounda (Sénégal). Revue d'Épidémiologie et de Santé Publique, 65, 189-196. https://doi.org/10.1016/j.respe.2016.10.061

Menick, D. M. (2002). Les abus sexuels en milieu scolaire au Cameroun resultats d'une recherche-action a Yaounde. Médecine Tropicale: Revue du Corps de santé colonial, 62, 58-62. https://www.lissa.fr/rep/articles/12038181

N'guessan, K., Bokossa, M., Boni, S., Kone, N., \& Bohoussou, K. (2004). Les violences sexuelles chez la femme: Une réalité africaine. Médecine d'Afrique Noire, 51, 306-310.

Nhundu, T. J., \& Shumba, A. (2001). The Nature and Frequency of Reported Cases of 
Teacher Perpetrated Child Sexual Abuse in Rural Primary Schools in Zimbabwe. Child Abuse \& Neglect, 25, 1517-1534. https://doi.org/10.1016/S0145-2134(01)00288-5

Nsengiyumva, A. (2018). Du sexe en echange des points en milieu scolaire: La pratique de Kwideribera. L'Homme-Revue française d'anthropologie, 18, 1-17. https://halshs.archives-ouvertes.fr/halshs-01804866

ONU Femmes (s.d.). Mettre fin à la violence à l'égard des femmes et des filles: Quelques faits et chiffres.

https://www.unwomen.org/fr/what-we-do/ending-violence-against-women/facts-and-f igures

Organisation mondiale de la santé (2005). Étude multipays de POMS sur la santé des femmes et la violence domestique à légard des femmes: Premiers résultats concernant la prévalence, les effets sur la santé et les réactions des femmes: Rapport Succinct. OMS.

Traore, Y., Mounkoro, N., Teguete, I., Djire, M., Diallo, A., Bagayogo, M., Sissoko, A., Dolo, A., \& Dolo, A. (2010). Clinical and Medico-Legal Aspects of Sexual Aggressions at Gabriel Toure Teaching Hospital. Le Mali Médical, 25, 27-30.

Unicef (2012). La situation des enfants dans le monde 2012: Les enfants dans un monde urbain (p. 156). UNICEF.

WHO, \& UNAIDS (2002). World Report on Violence and Health. Geneva: World Health Organization. 